\title{
Svarte blemmer i huden og Enterobacter i blodet
}

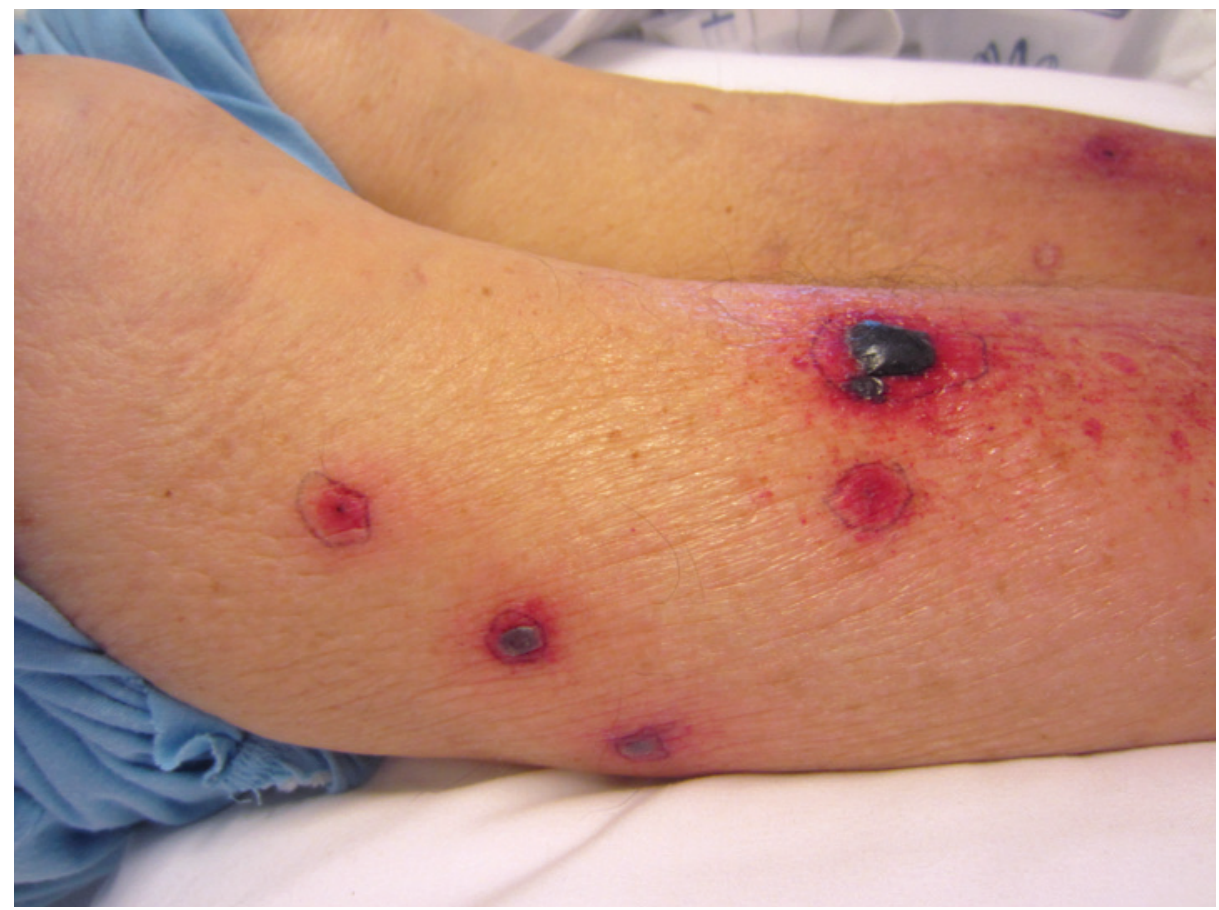

En kvinne i 80-årene med transformert follikulært lymfom var under cellegiftbehandling med rituksimab, cyklofosfamid, doksorubicin og bleomycin med vekstfaktorstøtte. Hun ble innlagt i nøytropen fase med feber og sykehistorie på én dag, med utvikling av flere små sirkulære hudforandringer ventralt på begge legger. Lesjonene var velavgrensede og eleverte. De var mørke sentralt, mens det var rødme i periferien. De klødde ikke og var smertefrie i begynnelsen.

Innleggelsesdagen økte omfanget betydelig - de målte mellom $0,5 \mathrm{~cm}$ og $5 \mathrm{~cm}$ i diameter. Senere oppsto hemoragiske bullae. Blodprøver ved innleggelsen viste uttalt nøytropeni $<0,2 \cdot 10^{9} / 1\left(1,7-8,2 \cdot 10^{9} / 1\right)$ og et CRP-nivå på $204 \mathrm{mg} / \mathrm{l}(<5 \mathrm{mg} / \mathrm{l})$. Det vokste Enterobacter cloacae i samtlige fire blodkulturer tatt innkomstdagen. På grunnlag av det kliniske bildet og oppvekst av E. cloacae ble diagnosen ecthyma gangrenosum stilt. Det ble ikke tatt biopsi.

Ecthyma gangrenosum er en infeksiøs, kutan vaskulitt med invasjon av bakterier eller sopp i adventitia og media i karveggen, noe som fører til utvikling av iskemisk nekrose. De første symptomene er ofte små papler, som i løpet av 1-2 dager utvikler seg til runde lesjoner med diameter mellom $5 \mathrm{~cm}$ og $15 \mathrm{~cm}$. Forandringene er karakteristiske, med sentral nekrose eller hemoragiske bullae med erytematøs randsone. Vaskulitt er til stede i den inflammerte randsonen. Dersom vevsprøven sendes til dyrking, kan etiolo- gisk agens ofte påvises. I starten er forandringene ikke smertefulle, men som regel blir de smertefulle etter 24 timer. Ofte forekommer lesjonene disseminert med predileksjonssted mellom navlen og knærne (1).

Echtyma gangrenosum forårsakes oftest av Pseudomonas aeruginosa, men det er også beskrevet tilfeller forårsaket av andre mikrober, da hyppigst fattigforgjærende, gramnegative intestinale stavbakterier samt arter innen Enterobacteriaceae.

Tidligere anså man at echtyma gangrenosum kun rammet pasienter med alvorlig nøytropeni kombinert med barrierebrudd, som for eksempel bruk av sentralvenøse tilganger. Imidlertid er tilstanden også beskrevet hos friske der ingen klar underliggende sykdom kunne påvises. Dette gjør at entydig assosiasjon til immunsvikt er omdiskutert (1).

Uten adekvat behandling kan tilstanden være raskt progredierende. Ved klinisk mistanke om echtyma gangrenosum bør man velge et antibiotikum med effekt mot P.aeruginosa. Vår pasient ble behandlet med meropenem i en uke, etterfulgt av peroral behandling med ciprofloksacin i ytterligere en uke.

Pasienten har gitt samtykke til at artikkelen blir publisert.

\section{Tor Henrik Tvedt}

tor.henrik.anderson.tvedt@helse-bergen.no Hematologisk seksjon
Silje Orstad

Steinar Skrede

Infeksjonsseksjonen

Medisinsk avdeling

Haukeland universitetssykehus

\section{Tor Henrik Tvedt (f. 1979)}

er overlege.

Forfatter har fylt ut ICMJE-skjemaet og oppgir ingen interessekonflikter.

\section{Silje Orstad (f. 1986)}

er lege i spesialisering.

Forfatter har fylt ut ICMJE-skjemaet og oppgir ingen interessekonflikter.

\section{Steinar Skrede (f. 1964)}

er seksjonsoverlege og førsteamanuensis II ved Klinisk institutt 2, Universitetet i Bergen.

Forfatter har fylt ut ICMJE-skjemaet og oppgir ingen interessekonflikter.

\section{Litteratur}

1. Vaiman M, Lazarovitch T, Heller L et al. Ecthyma gangrenosum and ecthyma-like lesions: review article. Eur J Clin Microbiol Infect Dis 2015; 34: $633-9$ 